\title{
Greywater Treatment Technologies
}

\author{
S. Christopher Gnanaraj, G. Lizia Thankam, K. Mukilan, K. PonRama Nivetha
}

\begin{abstract}
This survey intends to discover the different treatment for grey water by breaking down the grey water attributes, reuse gauges, execution and cost. The exponential development in populace causing increment in water request has prompted utilizing wastewater as a wellspring of water. One of the fundamental options for decreasing convenient water utilization in families, enterprises and business structures is the reuse of grey water. The audit uncovers that, whatever the nature of grey water is, the frameworks for treating grey water should comprise of procedures that can trap poisons and change over natural issue to mineralized mixes. The audit additionally uncovers that physical procedure alone are not adequate to ensure a sufficient diminishment of the organics, supplements and surfactants. The synthetic procedure can successfully expel the suspended solids natural materials and surfactants in the low-quality dark water. The best general exhibitions were seen inside the plans joining diverse kinds of treatment to guarantee compelling treatment of the considerable number of parts.
\end{abstract}

Keywords: Greywater, Reuse, Standards, Treatment Technologies, Water scarcity.

\section{INTRODUCTION}

Grey water known as Sullage, gets its name from its overcast appearance and from its status as being neither new nor intensely contaminated [1]. Grey water is characterized as urban wastewater barring any commitment toilets and by and large incorporates sources from showers, hand washing bowls, clothes washers, dishwashers and kitchen sinks [2]. A few creators take out kitchen squander water from other grey water streams. $50-80 \%$ of the aggregate family unit wastewater is grey water [3]. It contains less or no pathogens and $90 \%$ less nitrogen than black water [4]. Grey water speaks to up to $70 \%$ of aggregate expended water yet contains just $30 \%$ of the natural division and 9 to $20 \%$ of the supplements [5]. Contrasted with other ecological perspective preferences strong waste and black water, grey water as a rule gets slightest consideration [6]. Natural stacking is the significant distinction amongst grey water and sewage. The cost of treatment is less because of low level of treatment (sedimentation, filtration and adsorption)

Revised Manuscript Received on December 5, 2019

* Correspondence Author

S.Christopher Gnanaraj*, Department of Civil Engineering, Kalasalingam Academy of Research and Education, Virudhunagar, India. Email: s.christophergnanaraj@klu.ac.in

G.Lizia Thankam, Department of Civil Engineering, Kalasalingam Academy of Research and Education, Virudhunagar, India.

Email: g.liziathankam@klu.ac.in

K. Mukilan, Department of Civil Engineering, Kalasalingam Academy of Research and Education, Virudhunagar, India.

Email: k.mukilan@klu.ac.in

K.PonRama Nivetha, Department of Civil Engineering, Kalasalingam Academy of Research and Education, Virudhunagar, India.

Email: prnivetha19@gmail.com connected to the grey water. The conceivable reuse choice for the treated water are urinal and can flushing, water system of yards, washing of vehicles and windows, and protect wetlands, penetrate into ground (for energize of aquifers), farming and viticulture reuse. In spite of the moderately low convergence of contaminants, grey water constituents are known to be hard-headed [7].

It contains a large number of an indistinguishable contaminant from sewage water and for the most part introduce in bring down focus than sewage water, they can be well above universal drinking, washing, and water system water principles. The reuse of grey water in numerous parts of the world lessens the use of consumable water by up to $50 \%$, sewage ages spares cash and expanding the powerful water supply in districts where water system is required and shortage of water is more[8]. Reuse of grey water for on location water system is turning into a typical practice in whole around the world, especially in regions that face water request [9].There are distinctive kinds of frameworks plan from easy to modern framework planned by quality and sort of reuse [10]. Decentralized wastewater is picking up significance as the nation is confronting water interest for meeting different water employments [11]. The utilization of Sullage water decreases the weight on sewage treatment framework [12]. It advances the utilization of astounding water for versatile utilize just [13]. It additionally diminishes the reliance on huge foundations, for example, dams and desalination exchange plants in this way enhancing the nature of freshwater biological systems and lessening clashes over water assets [14]. Reusing of grey water will secure the amphibian biological systems by diminishing the preoccupations of freshwater, lessening the amount of supplements and other dangerous contaminants entering conduits [15]. Since grey water regularly contains a few centralizations of fecal markers and different pathogens, safe utilize requires some cleansing [16]. At the point when grey water is appropriately overseen, it can be a profitable assets for both cultivation and agribusiness producers [17].

The guidelines for dim water reusing relies upon area, application, it typically incorporates parameters, for example, natural, solids and microbiological substance of the water [18]. The contaminants that can be found in grey water involve an expansive scope of xenobiotic substance which is an engineered synthetic, including both natural polluting influences and metals [19].The advantages of reusing Sullage incorporates crisp water extraction, not very many effect on septic tank, ground water energize, security of ground water table[37]. The nearness of engineered mixes from dark water in regular water prompts stylish loses caused by froth which will cause poisonous impacts on condition and changes the bio-decent variety. 
On the off chance that grey water is gathered utilizing a different pipes framework from black water, it can be reused straightforwardly inside the home or cultivate and utilized promptly or handled and put away. On the off chance that put away, it ought to be utilized inside a brief timeframe.

In this investigation, the distinctive treatment strategies for grey water reuse are dictated by inspecting the distributed written works. Wastewater treatment in these days has turned out to be more typical as a result of shortage in numerous parts of the world and causes wellbeing effects. This paper goes for checking on the examination in a specific zone for the expulsion of different pollutants [42].

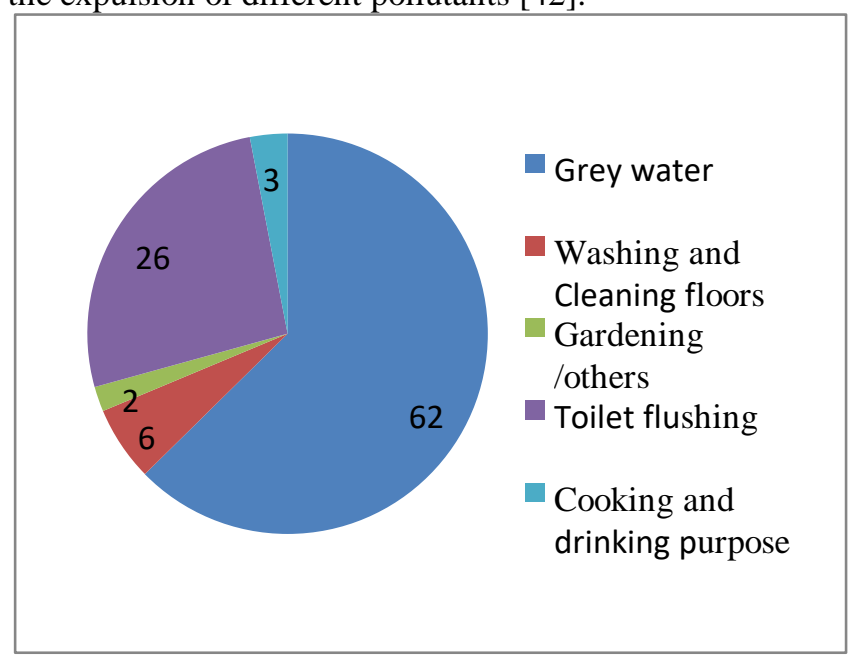

Fig. 1: Total water consumption [34]

\section{CHARACTERISTICS OF GREYWATER}

The qualities of family unit grey water can change contingent upon the quantity of family tenants, their age, wellbeing status, tap water sources, water utilization examples and house hold items utilized, (for example, Soaps, Shampoos, Detergents, Mouthwash, Tooth glue, hairdo, Shaving cream and body oils)[1].

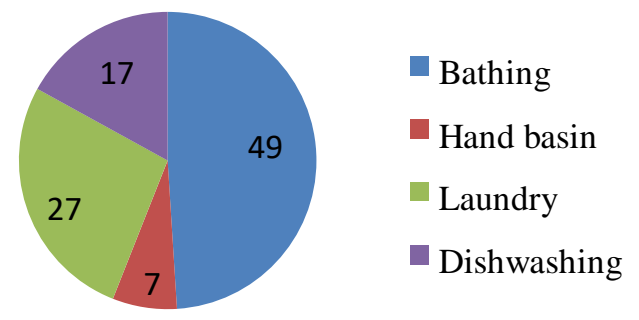

\section{FIG. 2: GREY WATER GENERATION}

Dim water attributes are profoundly affected by social and social conduct of the home, accessibility of water utilization isolating dark water from dark water lessens the risk causes by the pathogens [35].

TABLE I

\section{COMPOSITION OF GREYWATER}

\begin{tabular}{|l|l|l|l|}
\hline S.No & Parameters & Unit & Ranges \\
\hline 1 & Suspended solids & $\mathrm{mg} / \mathrm{L}$ & $45-350$ \\
\hline 2 & Turbidity & $\mathrm{NTU}$ & $22-220$ \\
\hline 3 & BOD $_{5}$ & $\mathrm{mg} / \mathrm{L}$ & $90-290$ \\
\hline 4 & COD & $\mathrm{mg} / \mathrm{L}$ & $280-800$ \\
\hline 5 & Oil \&Grease & $\mathrm{mg} / \mathrm{L}$ & $37-78$ \\
\hline 6 & Coli form & $\mathrm{Cu} / 100 \mathrm{ml}$ & $0-500-$ \\
& & & 10000 \\
\hline 7 & $\begin{array}{l}\text { Total Dissolved } \\
\text { Solids }\end{array}$ & $\mathrm{mg} / \mathrm{L}$ & $126-175$ \\
\hline 8 & Temperature & ${ }^{\circ} \mathrm{C}$ & $18-38$ \\
\hline 9 & Nitrite & $\mathrm{mg} / \mathrm{L}$ & $<0.1-0.8$ \\
\hline 10 & Ammonia & $\mathrm{mg} / \mathrm{L}$ & $<0.1-25.4$ \\
\hline 11 & $\begin{array}{l}\text { Total Kjeldahl } \\
\text { Nitrogen }\end{array}$ & $\mathrm{mg} / \mathrm{L}$ & $2.1-31.5$ \\
& $\begin{array}{l}\text { Total } \\
\text { phosphorous }\end{array}$ & $\mathrm{mg} / \mathrm{L}$ & $0.6-27.3$ \\
\hline 12 & Ph & ----- & $6.6-8.7$ \\
\hline 14 & Conductivity & $\mu \mathrm{s} / \mathrm{cm}$ & $\begin{array}{l}1.4- \\
2.9 \mathrm{mS} / \mathrm{m}\end{array}$ \\
\hline 15 & Sodium & $\mathrm{mg} / \mathrm{L}$ & $29-230$ \\
\hline
\end{tabular}

The investigation of the grey water qualities by various classes shows that kitchen grey water and clothing grey water are higher in both natural and physical toxins contrasted with the lavatory and the blended grey water [3]. The grey water has much lower oxygen request than black water [4]. Grey water is separated from black water by natural material and supplements introduce [6]. The grey water attributes are affected by elements, for example, way of life, social and social conduct of occupants and water accessibility [10]. The $\mathrm{pH}$ was in the range from 6.3 to 8.1. The clothing water will have a greater amount of antacid nature yet on blending with nearly high volume of showering water and kitchen water, the $\mathrm{pH}$ comes to above range [11]. Contrasting and different species generally coagulates recommends that the crashes in grey water apply a moderately low charge request to the water per unit of natural material [18]. Putting away grey water for $48 \mathrm{hrs}$ at 19 to $26^{\circ} \mathrm{C}$ deteriorates its quality and organic debasement deliver terrible smell causing a stylish issue, pathogens rearing and mosquito reproducing which are a wellbeing problem[20].

\section{GREYWATER REUSE GUIDELINES}

In 2006 the World Health Organization (WHO) post a rules for grey water reuse for confined and non-limited horticultural water system. The rule just aides the microbial prerequisites without considering the physical and compound parameters. Compared to the unhindered nonconsumable reuses the confined non-consumable reuses have bring down water quality necessities [3]. In 2009 april, the provinces in the state has declared uniform pipes code to utilize the clothes washer squander water for the subsurface water system. This 
code ought to apply just for the territories which are not adjusted by freely claimed sewer framework.

As per the rules of joined state natural generation office 2004 it can be utilized for urban reuse incorporates a wide range of scene water system, latrine flushing, fire security, business aeration and cooling systems. According to the rules of focal contamination control board 2012 the water should be release into inland surface water [35].

\section{GREYWATER TREATMENT TECHNOLOGIES}

The advancements perplexing for treating grey water incorporate physical, compound and organic frameworks. Grey water reuse should progressively turn out to be a piece of an arrangement of incorporated activities towards the normal utilization of water, since this kind of profluent speaks to a substitute hotspot for non-versatile utilizations, with widely materialness not just in private, business and mechanical structures . A large portion of the advances are gone before by a pre-treatment technique for strong fluid division and took after by post treatment as sanitization. To stay away from the stopping up of the ensuing treatment, the pre-medications, for example, screen, channel packs and channels are connected to diminish the measure of particles and oil and slick substance. The cleansing advance is utilized to meet the microbiological prerequisites.

\section{A. Physical Treatment}

The primary advances predominantly began with physical treatment choices, for example, coarse filtration or films post treatment with purification [21]. Dim water is dealt with by moderate sand channel. The outcome found that lessening in suspended solids and turbidity are $72.8 \%$ and $67 \%$ separately. COD outlet is averagely $45.86 \mathrm{mg} / \mathrm{l}$. The most extreme expulsion effectiveness of $75.85 \%$ was ingested for COD and $89 \%$ for BOD. Some straightforward methods are two phase filtration and synthetic sterilization evacuate coli frames however stays high in turbidity and natural contamination. The smaller scale filtration film demonstrates powerful evacuation of shading, COD, turbidity expulsion and suspended strong cleansing framework and evacuation proficiency was $71.8 \%$ in COD, $5 \%$ in SS and the effectiveness was extremely successful contrasted with moderate sand filter.[5] Using the channel segments made out of two indistinguishable misty uPVC sections stuffed with rock layer, media grains and smashed igneous rock and silica sand, the COD, TSS and oil and oil fixation were diminished by $48 \%, 65 \%$ and $67 \%$ subsequent to settling of dark water for 1 hour in the blending holder. The fixation E.coli in settled dark water added up to $6.9 * 107( \pm 2.4 * 107) \mathrm{cfu}(100 \mathrm{ml})^{-1}[13]$. The exploratory setup for this grey water treatment framework incorporates gathering tank, a pumping gadget, a filtration framework and an UV cleansing unit has a treatment productivity of expulsion of solids and natural issues is to a great extent accomplished by the channel, while the sterilization unit is chiefly in charge of the microbiological lessening. $\mathrm{pH}$ isn't influence by comparable incentive when treatment. Lessening of 16-39\% [2]. The channel containing the sand, slate squander and 2carbon channels were based on backings of unbending PVC funnels has no huge contrasts between the treatment parameters for the $\mathrm{pH}$ and add up to and thermo tolerant coli frames; nonetheless, huge contrasts were found in the turbidity, evident shading, COD, BOD. Model of Rapid sand channel for the treatment of wastewater utilizing a minimal effort adsorbent, for example, neem leaf powder essentially aid the evacuation of BOD, COD, TSS, TDS, DO, hardness, EC and will enhance the $\mathrm{pH}$ nature of the gushing which demonstrates that treated grey water are appropriate for water system principles as per WHO rules [29].

\section{Sand and Gravel Filter}

The wastewater moves through a channel medium - sand or rock in low-tech grey water channels. The fundamental treatment process involves the maintenance of particles by channel material and cleaning process because of natural action in the bio-film on the sand and rock.

\section{Cabinet Compacted Sand Filter}

The Drawer Compacted Sand Filter (DCSF) is an adjusted plan for a sand channel in which the sand layer is separated into a few layers, every one of which is $10 \mathrm{~cm}$ high and set in a versatile cabinet isolated by a $10 \mathrm{~cm}$ space. A lab-scale DCSF was outlined and worked for 330 days nourished by engineered grey water. Results demonstrated that DCSF could evacuate $>90 \%$ of natural issue and aggregate suspend solids for all measurements. No noteworthy distinction was seen as far as general channel proficiency between heaps of all parameters [37]. It diminishes the issue, for example, obstructing, causing of awful odour [8].

\section{Filter Using Marble Chips}

The grain estimate conveyance for marble chips ranges from 4.75 to $20 \mathrm{~mm}$. The most extreme evacuation got for turbidity, COD and aggregate solids were $75.6 \%, 59.4 \%$ and $43.16 \%$ separately at 8 hour maintenance time. In sand channel the expulsion effectiveness of turbidity has been recorded up to $81.89 \%$ [36].

\section{Filter Using Jute Coir}

In this media the expulsion of COD proficiency is $59.03 \%$ out of 8 hour maintenance time. The permeable structure in this media serves to develope the thick matt of particles and furthermore lessens the COD [36].

\section{Setup Using Blend of Zea Maize and Activated Carbon:}

Dark water treatment framework at research center scale was intended for 5 liters limit, confined to five phases of physical tasks, for example, crude dim water unit of 10 liters limit, sedimentation unit of 10 liters limit, first filtration unit of sand and rock of 5 liters limit, second double filtration unit of 5 liters limit containing granular initiated carbon and zea maize feed and putting away unit for treated dim water of 5 liters limit. The channel media utilized as a part of the filtration unit were effortlessly accessible and characteristic materials, for example, fine particles of sand 0-2 mm, rock of $8-10 \mathrm{~mm}$ and $1820 \mathrm{~mm}$ size, granular initiated carbon, zea maize feed which is the waste material utilized for the analysis. The bed stature of every material in the filtration framework was resolved and

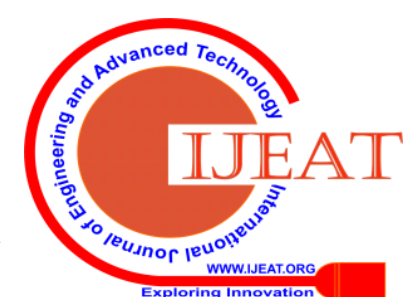


finished by the experimentation. The stream of water from crude dark water unit to the putting away unit of treated dim water is by gravitational stream. Because of cleanser and soil defilements, the levels of aggregate broke down solids (TDS) and Total suspended solids (TSS) of wastewater were high running from $688 \mathrm{mg} / \mathrm{l}$ and $155 \mathrm{mg} / \mathrm{l}$ individually. The $\mathrm{pH}$ and turbidity of wastewater ranges from 8.39 and 145NTU individually.

The sedimentation and filtration has diminished the nature of wastewater to be utilized for the filtration of sand and rock channel and afterward through double channel of zea maize grain and initiated carbon. Add up to suspended solids was diminished from $155 \mathrm{mg} / \mathrm{l}$ to $10 \mathrm{mg} / \mathrm{l}$, add up to broke down solids from $688 \mathrm{mg} / \mathrm{l}$ to $645 \mathrm{mg} / \mathrm{l}$, turbidity from 145 to 13.86 NTU, add up to hardness lessened from $522 \mathrm{mg} / 1$ to $273 \mathrm{mg} / \mathrm{l}$. Furthermore the natural load as Chemical oxygen request (COD) lessened from $176.7 \mathrm{mg} / \mathrm{l}$ to $98.23 \mathrm{mg} / \mathrm{l}$ and Biochemical oxygen request (BOD) from 56.65 to 31.74 $\mathrm{mg} / \mathrm{l}$. The treatment framework has diminished the natural stacking about half of the first natural load [37].

\section{Downstream Hanging Sponge}

The DHS bio-tower of size $12 \mathrm{~cm} \mathrm{x} 12 \mathrm{~cm} \mathrm{x} 50 \mathrm{~cm}$ and of 4.2 liters viable volume was chosen as the treatment unit. Wipe solid shapes of size $2.5 \mathrm{~cm}$ sides were filled in the reactor in two portions of every $10 \mathrm{~cm}$ tallness. The wipe accounted the $40 \%$ of the aggregate reactor volume. The $3 \mathrm{D}$ shapes were filled haphazardly in the channel. At the main, a punctured plate was utilized to consistently appropriate the influent. Manufactured wastewater was encouraged in to the bio-tower and The pro fluent from the bio-tower was given a two hour settling and it is utilized for the examination. The evacuation efficiencies were $77 \%, 90 \%, 54.6 \%$ and $32.9 \%$ for COD, BOD, alkali nitrogen and phosphates separately [40].

\section{B. Chemical Treatment}

Chlorine sterilization of grey water by add up to coli shape inactivation disease. The viability of cleansing was almost enjoyed with molecule estimate. Bigger molecule protected whole coli shapes from inactivation and sterilization adequacy diminished with expanding in molecule measure. The chlorine sanitization disclose that up to $91 \%$ of aggregate coli frames in chlorinated grey water were molecule associated[5]. The synthetic process connected for dark water treatment incorporate coagulation ,photograph synergist oxidation, particle trade and granular enacted carbon and so forth. Coagulation with aluminum salt lessened the COD, the BOD, the turbidity, TN and PO43. The attractive particle trade gum process neglected to decrease the scope of turbidity and the BOD to the level for both limited reuses [3]. Hydrogen peroxide go about as the best disinfectants, the expulsion of BOD and COD was substantially more powerful with the grey water [16]. Electro coagulation treatment is late innovation that a blend of aluminum and graphite evacuates add up to COD and pathogens of $70 \%$ and $99.9 \%$ separately [10].Coagulation supported sedimentation jostle test is a lab test which modify the variety coagulant, alteration of $\mathrm{pH}[23]$. Ferric chloride is the coagulant with high productivity, the compound leaves slight remaining shading, great expulsion of turbidity [12]. An propelled oxidation process in view of photograph reactant oxidation with titanium dioxide and UV was connected and the evacuation of organics and aggregate coli shape was $90 \%$ and $6 \log$ separately [3]. The untreated dim water having abnormal state of metal particle contaminants, the $\mathrm{pH}$ changed alum. Quartz sand filtration of alum treated dark water the level of some particle the contaminants expanded [24].

\section{Normal Coagulants}

Normal coagulant assume an imperative part in the expulsion of turbidity and contaminants. Normal coagulants, for example, concentrates of miniaturized scale living beings or plant starting point (illustrations: Narmali seeds, Moringa seeds, Okra seeds, Cassava seeds, Dutchuslabla , Broad beans, Flava beans, Water melon)[31]

\section{Artificial Coagulants}

Manufactured coagulants incorporates Aluminum sulfate, Aluminum chloride and Sodium aluminate, Ferric sulfate, Ferrous sulfate, de and Ferric chloride sulphate [31]

\section{Electro-Coagulation}

Electro-coagulation is the strategy with stainless steel cathode as anode in the arrangement of bipolar association. In the examination of treated waste water it demonstrates that greatest evacuation of BOD, COD, Suspended Solids were $92.71 \%, 88.76 \%$ and $93.1 \%$ respectively[32]

\section{Alum Treatment}

The water is dealt with by alum filtration through a glass segment with medium measured quartz sand and cotton fleece plunged at the base [24]. The alum is included with crude water responds with bicarbonate alkalinities the floc draws in fine molecule and suspended molecule

\section{Biological Treatment}

Propelled oxidation techniques, for example, moving bed bio-film reactor were utilized for expulsion of colors [22]. For strong fluid partition, the film bioreactor joins biodegradation with layer filtration because of its procedure, security and its capacity to expel pathogens, COD and BOD are about high in go [3]. 100\% aggregate coli form evacuated in the film bio reactor. Pivoting natural contactors can productively treat dim water with evacuation of BOD and TSS efficiencies of 93-96\% and 84-95\% [11].

\section{Moving Bed Bio-Film Layer Reactor}

It evacuates hair shading by $80 \%$ effectiveness and it expends vitality under $1.3 \mathrm{kwh} / \mathrm{m} 3$ grey water with various loadings and fluctuating encompassing temperature [10].

\section{Submerged Sequential Bunch Reactor}

Grey water treated with SBR is utilized with the end goal of vehicle washing, latrine flushing, fire protection and so on. This framework expels $94.57 \%$ of BOD, $84.85 \%$ of COD, $89.73 \%$ of SS and $63.89 \%$ of TSS [10].

\section{Vermifilter}

The examination was done in vermifilter pack that contains rock with the layer of dark cotton soil to finish everything. It shapes the vermifilter bed. It has arrangement to gather separated water at the base of the accumulation chamber which opens out through a

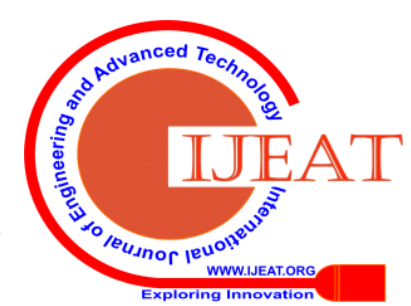


pipe fitted with tap. For vermifilter dark cotton soil having $\mathrm{pH} 7$ is utilized. The bottommost layer is made of rock of size $20 \mathrm{~mm}$ and it topped off to the profundity of $40 \mathrm{~mm}$. Over this is the total of $10 \mathrm{~mm}$ size topped off to profundity of $30 \mathrm{~mm}$. On the highest point of this is sand going through $2.36 \mathrm{~mm}$ IS Sieves were topped off to profundity of $30 \mathrm{~mm}$. The highest layer of soil blended with cow excrement in 1:3 extent up to profundity of $120 \mathrm{~mm}$ in which the night crawlers are discharged. The rate lessening in convergence of COD in vermifilter ranges from 74 to 80 and BOD ranges from 85 to 93 [38].

\section{Treaatment Using Canna Plants}

The trial setup comprises of two units and it was worked in outside. The span of every tub was $0.6 \mathrm{mx} 0.4 \mathrm{mx} 0.3 \mathrm{~m}$ and vertical container were utilized to hold the wastewater. The limit of every vertical basin was 20 liters. A longitudinal incline was given to empower the stream of wastewater gravitationally from channel to outlet. The two pilot units were filled (from base to top) of $0.1 \mathrm{~m}$ comprised of coarse total, next of $0.1 \mathrm{~m}$ comprised of sand. Initially unit is planted with Canna flaccida and second unit with Canna indica and both were planted with the plants in $3 \times 3$ columns. Canna indica is compelling and the BOD ( 3 days @ $\left.27^{\circ} \mathrm{C}\right)$ content reductions from $22 \mathrm{mg} / \mathrm{l}$ to $5 \mathrm{mg} / \mathrm{l}$ and COD expulsion was from $100 \mathrm{mg} / \mathrm{l}$ to $28 \mathrm{mg} / \mathrm{l}$ and TSS was from $12 \mathrm{mg} / \mathrm{l}$ to $5 \mathrm{mg} / \mathrm{l}$ which is protected creation for local re-utilization [39].

Bio-electrochemical framework (BES) is the innovation with awesome potential for vitality productive wastewater treatment. BES has preference of microbial co-operations join with a strong electron acceptor to accomplish bio vitality recoup from natural compounds[42].

\section{CONCLUSION}

The real objective of dim water reuse and recovery is to decrease the suspended solids and natural quality and smaller scale creatures because of its association with the physical and wellbeing attributes of the item wastewater. Physical procedures have been appeared to evacuate solids yet are less compelling for natural expulsions [28]. Contrasting the physical, organic and concoction treatment; substance treatment assumes an indispensable part in a grey water treatment. Sanitization likewise assumes a critical part on treating it artificially, however joined with physical took after by purification is proposed. Waste water and normal water extractor expels the two poisons and contaminations from water and this can be reuse to decrease worry of economy on nation and it influences the earth and furthermore in a roundabout way it lessens water pollution[43].

\section{REFERENCES}

[1]. R.T.Pachkor and Dr.D.K.Parbat, "A Literature Review on Integrated Approach for Greywater Treatment", International Journal for Research in Applied Science \& Engineering Technology (IJRASET), Volume 5 Issue IV, April 2017 ISSN: 2321-9653.

[2]. C.Santos, F.Taveira-Pinto, C.Y.Cheng and D.Leite, "Development of an experimental system for greywater reuse", Desalination 285 (2012) 301-305

[3]. Fangyue Li, Knut Wichmann and Ralf Otterpohl, "Review of the technological approaches for greywater treatment and reuses", Science of the Total Environment 407 (2009) 3439-3449.

[4]. ShaikhaBinte Abedin and Zubayed Bin Rakib, "Generation and Quality Analysis of Greywater at Dhaka City", Environmental Research, Engineering and Management, 2013. No. 2(64), P. 29-41 ISSN 2029-2139.

[5]. Nirmala.M.D., Muthukumar.K. and Ravikumar.G, "Review Of Greywater treatment methods", International Conference on Current Research in Engineering Science and Technology (ICCREST2016).

[6]. Charles B. Niwangaba, Patrick Dinno, IssacWamala, S.SaharDalahmeh, Cecilia Lalander and Hakan Jonsson, "Experiences on the implementation of a pilot grey water treatment and reuse based system at a household in the slum of Kyebando-Kisalosalo, Kampala”, Journal Of Water Reuse and Desalination 0.04, 2014.

[7]. Chidozie C Nnaji, Cordelia N mama, Arinze Ekwueme and TerlumunUtsev, "Feasibility of a FiltrationAdsorption Grey Water Treatment System for developing Countries", Hydrology Current Research 2013, ISSN 2157-7587.

[8]. Shobha Kundu, Isha P. Khedikar, Aruna M. Sudame, "Laboratory Scale Study for Reuse of Greywater",

Journal of Mechanical and Civil Engineering (IOSRJMCE), Volume 12, Issue 3 Ver.1 (May - June 2015) PP 40-47.

[9]. Adi Maimon, Eran Friedler and Amit Gross,

"Parameters affecting greywater quality and its safety for reuse", Science of the Total Environment 487 (2014) 20-25.

[10]. ParameshwaraMurthy.P.M., B.M.Sadasiva Murthy and Kavya.S, "Greywater Treatment \& Reuse: A

Technological review”, Global Journal for Research Analysis Volume-5, Issue-3, March-2016. ISSN No 2277-8160.

[11]. KarnapaAjit, "A Review on Greywater Treatment and Reuse", International Research Journal of Engineering and Technology (IRJET), Volume:03 Issue:05, May-2016.

[12]. R.Saranya, S.Shanmugapriya and R.Subashini, "Experimental Study on Treatment Of Sullage Waste

Water Using Coagulants", SSRG International Journal Of Civil Engineering- (ICRTCEMT-2017) - April 2017.

[13]. A.Y.Katukiza, M.Ronteltap, C.B.Niwagaba, F.Kansiime and P.N.L.Lens, "Greywater treatment in Urban slums by a Filtration system: Optimisation of the filtration medium", Journal of Environmental Management 146 (2014) 131-141.

[14]. Mariah Siebert Zipf, IvoneGohr Pinheiro and Mariana GraciaCnegero, "Simplified greywater treatment systems: Slow filters of sand and slate waste followed by granular activated carbon", Journal of Environmental management 176 (2016) 119-127.

[15]. Shaikh, Sk Sameer and Sk Younus, "Greywater Reuse: A Sustainable Solution of Water Crisis in

Pusad city in Maharastra, India”, International Journal on Recent and Innovation Trends in Computing and Communication (Feb. 2015) Volume: 3 Issue: 2 ISSN: 2321-8169.

[16]. Zeev Ronen, Adriana Guerrero and Amit Gross, "Greywater disinfection with the environmentally friendly Hydrogen Peroxide Plus (HPP)", Chemosphere 78 (2010) 61-65.

[17]. J.S.Lambe and R.S. Chougule, "GreywaterTreatment and Reuse", Journal of Mechanical and Civil Engineering (IOSR-JMCE) ISSN: 2278-1684, PP: 20-26

[18]. Marc Pidou, lisa Avery, Tom sephenson, Paul Jeffrey, Simon A. Parsons, Shuming Liu, Fayyaz A. Memon and Bruce Jefferson, "Chemical Solutions for Greywater Recycling”, Chemosphere 71 (2008) 147 - 155.

[19]. E.Eriksson and E.Donner, "Metals in Greywater: Sources, presence and removal efficiencies", Desalination 248 (2009) 271-278.

[20]. Lina Abu Ghunmi, Grietje Zeeman, Manar Fayyad and Jules B. Van Lier, "Greywater Treatment Systems: A Review"

[21]. Dr.MarcPidou, Dr.Fayyaz Ali Memon, Prof. Tom Stephenson, Dr.Bruce Jefferson and Dr.Paul Jeffrey, "Greywater recycling: A review of treatment options and applications", Institution of Civil Engineers, Engineering Sustainability, Vol.160.

[22]. Sunil J. Kulkarni, Pallavi M. Kherde, "Research on Advanced Biological Effluent Treatment: A Review", International Journal of Research and Review, EISSN: 2349-9788: P-ISSN:2454-2237.

[23]. Prasant Tayde, Chaitanya Shastri, Bhoomi Shah,

Nitesh Asabe, Dr. Hansa Jeswani, "Use of Sullage for Non-Potable Purpose", 2015 International Conference on Technologies for Sustainable Development (ICTSD-2015), Feb. 04-06, 2015.

[24]. Joseph B. Skudi, Ruth Wanjau, Jane Murungi and C.O.Onindo, "Alum Treated Greywater for Toilet Flushing, Mopping and Laundry work”, Hydrology Current Research, Volume 2, Issue 2, ISSN: 21577587.

[25]. Mr.Amol Ashok Inamdar, "Sullage Water Treatment Technique", International Journal of Innovative studies in Sciences and Engineering Technology, Volume 2, Issue 12, ISSN 2455-4863. 


\section{Greywater Treatment Technologies}

[26].LongD.Nghiem, Nadine Oschmann, Andrea I.Schafer, "Fouling in greywater recycling by direct ultrafiltration", Desalination 187 (2006) 283-290.

[27]. J.G.March and M.Gual, "Studies on Chlorintion of Greywater", Desalination 249 (2009)317-322.

[28]. GideonP.Winward, Lisa M.Avery, Tom Stephenson and Bruse Jefferson, "Chlorine disinfection of greywater for reuse: Effect of organics and particles"' Water research 42 (2008) 483-491. [29]. Sandhya Pushkar singh and Nusrat Ali, "Treatment of domestic wastewater by Rapid Sand Filter for Reuse in Irrigation Purpose", International Journal for Scientific Research \& Development Vol. 4, Issue 04, 2016 ISSN: 2321-0613.

[30]. J.de Koning, D.Bixio, A.karabelas, M.Salgot and A.Schafer, "Characterization and assessment of water treatment technologies for reuse", Desalination 218(2008) 92-104

[31]. S.N.Ugwu, A.F.Umuokoro, E.A.Echiegu, B.O.Ugwuishiwu and C.C.Enweremadu,

"Comparative Study of use of natural and artificial coagulant for the treatment of Sullage"

[32]. P.Santhosh, D.Revanth and K.Saravanan, "Treatment of Sullage Wastewater by electro Coagulation using Stainless Steel Electrons",

[33]. J.K.Braga and M.B.A.Varesche, "Commercial Laundry Water Characterization", American Journal of Analytical Chemistry, 2014,5, 8-16

[34]. Golda A.Edwin, PoyyamoliGopalswamy and

Nandhivarmammuthu, "Characterization of domestic greywater from point source to determine the potential for urban residential reuse", Appl Water Sci (2014), 4:39-49.

[35]. Dilip M. Ghatidak, Kunwar D, Yadav "Characteristics and treatment of greywater -a review"

[36]. Anudeep nema, Kunwar D. Yadav and Robin A.Christian, "Effect Of Retention Time On Primary Media For Grey Water Treatment" [37]. Bessy John and Bindhu.G, "Greywater treatment by Drawer Compacted Sand Filter with Silver coated Sand", International Journal of Science, Technology and Engineering, Volume 3, Issue 10, April 2017.

[38]. A.M. Kharwadea and Isha. P. Khedikar, "Laboratory Scale Studies On Domestic Grey Water Through

Vermifilter and non-vermifilter", Journal of Engineering Research and Studies, E-ISSN09767916.

[39]. Dr.H.Karibasappa, A.Akila, N.Dhanabal, R.Dharani,

K.Dhinesh, "An Experimental Investigation on Recycling of Grey Water Naturally by Using Canna

Plants", International Journal of Innovative Research in Science, Engineering and Technology, Vol 6, Issue 3, March2017.

[40]. Anjali P Sasidharan1 and Meera V, "Performance evaluation of treatment of greywater by down-flow hanging sponge bio-tower using aerated aerobic sludge and microalgae chlorella", International Journal of Engineering Research and Science \& Technology, ISSN: 2319-5991, Vol 2 No 4 November 2013.

[41]. OumarSall ,Yukio Takahashi "Physical, chemical and biological characteristics of stored greywater from unsewered suburban Dakar in Senegal" Urban water journal vol 3,no 3,September 2006,153-164.

[42]. Sunil.J. Kulkarni ,Ajaygiri K. Goswami "Application and advancement in treatment of wastewater by membrane" ISSN: 2277-9655

[43]. Andreas N. Angelkis, shane A. Snyder, "Wastewater treatment and reuse : past, present and future" ISSN: 2073-4441.

\section{AUTHORS PROFILE}

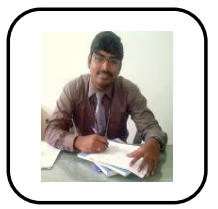

S. Christopher Gnanaraj, Working as a assistant professor in Department of Civil Engineering Kalasalingam Academy of Research and Education. He has a more than six years of teaching and research experience. His area of specialization is Structural Engineering and area of research is SCC, HSC, GPC \& EVS. He has published various papers in reputed journals in these areas. For any queries contact at christophergnanaraj@gmail.com

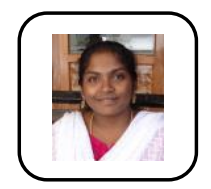

G. Lizia Thankam is a Research Scholar at Academy of Research and Education. Who graduated both her UG and PG degree from Karunya University, Coimbatore. She preferred to be in teaching till 2018 at Karunya University,Coimbatore and Kalasaligam University,Virudhunagar. She has modest publications in reputed journals.

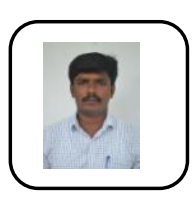

Mukilan K Completed his Master of Engineering in the field of Construction Engineering and Management in RVS Technical Campus, Coimbatore in the year of 2015. He completed his Bachelor of Technology under Kalasalingam University in the year of 2012. He has more than five years of experience in teaching. He has published various papers in the reputed journals. His main thrust research areas are Construction management

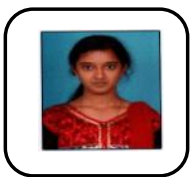

Pon Rama Nivetha $\mathbf{K}$ completed her B.tech in Civil Engineering from Kalasalingam Academy of Research and Education. Her area of interest is environmental engineering and construction management. 